\title{
Effects of roof configuration on natural ventilation for an isolated building
}

\author{
L.K. Moey ${ }^{1 *}$, M.F. Kong², V.C. Tai1 , T.F. Go ${ }^{3}$, N.M. Adam ${ }^{4}$ \\ ${ }^{1}$ Centre for Modelling and Simulation, Faculty of Engineering, Built Environment \& Information Technology, SEGi University, 47810, Selangor, \\ Malaysia \\ Phone: +60361451777 \\ 2 Faculty of Engineering, Built Environment \& Information Technology, SEGi University, 47810, Selangor, Malaysia \\ ${ }^{3}$ Centre for Advance Materials and Intelligent Manufacturing, Faculty of Engineering, Built Environment \& Information Technology, SEGi University, \\ 47810, Selangor, Malaysia \\ ${ }^{4}$ Department of Basic Science and Engineering, Universiti Putra Malaysia Bintulu Sarawak Campus, 97008, Sarawak, Malaysia
}

\begin{abstract}
Numerical analyses based on CFD steady RANS were conducted to investigate the effects of roof configuration on wind-induced natural ventilation for an isolated roofed building. Gable roof and saltbox roof building models were tested with $15^{\circ}, 25^{\circ}, 35^{\circ}$ and $45^{\circ}$ roof pitch in present study. The flow field information and flow characteristics were obtained from the contours and plots generated by CFD. In accordance to the increment of roof pitch, the turbulence kinetic energy and mean velocity ratio show vigorous response. The flow separated at the windward corner do not reattach onto the roof, thus induced higher velocity gradient and form a large vortex at the roof ridge. The vortices behind then building caused by the flow separation at the roof ridge extend along the mixing layer and spread up to the roof. The pressure differences mainly rely on the roof shapes. Greater pressure differences between the upstream, interior and downstream was observed in saltbox roof cases. This is due to the extended roof height which boosted the impinging effect caused by the incoming wind. Generally, the saltbox roof configuration exhibit better performance than gable roof in terms of the measured parameters.
\end{abstract}

ARTICLE HISTORY

Received: $14^{\text {th }}$ Nov 2020

Revised: $21{ }^{\text {st }}$ Mar 2021

Accepted: $18^{\text {th }}$ May 2021

\section{KEYWORDS}

Natural ventilation; roof configuration; computational fluid dynamics (CFD); steady RANS; ventilation rate.

\section{INTRODUCTION}

Natural ventilation has emerged from the high demand of built environment with satisfying energy-efficiency and sustainability. It required appropriate building designs and presence of necessary architectural elements. The energyefficiency of a building can be improved by optimising the building form, ceiling, building orientation, façade design and shadow quality [1]. Roof often plays an important role in optimizing energy-efficiency of building among the aforementioned elements. It accounts up to 50\% of building's solar energy gain. Moreover, especially in humid and rainy region, roofs and eaves should be considered as dominant factors protecting urbans from rain and glare. Roof configurations have aesthetic and semiotic values in different climates and cultures. A certain type of roof often insinuates the characteristics of local nature, culture and climate [2]. Therefore, roof configuration is perceived of capable to change the wind flow pattern and characteristics of building $[3,4]$. The performance of ventilation can be predicted by several alternatives including experiments, analytical and/or semi-empirical formulae and simulations $[5,6]$. In the past decade, numerical analysis based on computational fluid dynamics (CFD) are mainstream in evaluating the performance of ventilation $[5,7]$. Compared to conventional methods, CFD provides complete flow field data, allows customizations of model scales and full control over boundary conditions. These allow the parametric studies of ventilation performance of building to be performed easily and efficiently. For these reasons, CFD was employed in most parametric studies on ventilation performance evaluation and enhancement [5].

Gable roof is one of the most classic and frequently occurring roof shapes around the world [8] for snow drifting prediction purpose in snowy regions. In contrary, in hot and humid climate region, gable roof has been proved to have positive effects on natural ventilation [9]. However, there are only a few comprehensive studies that examined the impact of gable roof configuration on natural ventilation. Tominaga et al. [7] performed wind tunnel experiments and CFD simulations to study the airflow around isolated-gable roof building. This study confirmed that gable roof pitch affects the streamlines, distribution of turbulent kinetic energy (TKE), pressure coefficient and U/Uref around the building. Badas et al. [9] studied the effect of gable roof on natural ventilation in two-dimensional urban. Two-dimensional CFD simulation was performed by alternatives of RANS modelling between series of identical gable roof building with various roof angles. The results show that roof slope has a moderate influence in the aspect ratio threshold fluid dynamics regimes separations. Nevertheless, gable roof meaningfully enhances the air change rate $(\mathrm{ACH})$ between canyon and thus promotes pollutant and heat dispersion. Zhou et al. [8] studied the impact of gable roof slope on snow distribution with a series of two-dimensional CFD simulations and wind tunnel experiments. According to his study, gable roof can be categorized into two categories which is low $\left(0^{\circ}\right.$ to $15^{\circ}$ roof pitch) and high slope (15 roof pitch and above). The roof 
slope affects the flow separation at the leading edge and roof ridge, which subsequently affects the ventilation performance.

Based on the literature review, a comprehensive study of gable roof has yet to be presented. Most of the studies conducted on gable roof emphasized the effect of roof slope. Gable roof comes with different types and design. However, minor changes on the roof shape and geometry may also have effects on natural ventilation of the isolated building. This paper aims to fill this aforementioned gap with a series of 3D steady RANS CFD simulations. Effects of different gable roof configurations on natural ventilation is investigated. The remaining of this paper is organized as follows: Section 2 quotes and outlines the wind tunnel experiments by Karava et al. [10] for validation purposes. Section 3 details the settings of computational simulations and boundary conditions of CFD simulations. The results obtained are analyzed and discussed in section 4, alongside with discussion on the effect of gable roof configurations. Finally, section 5 concludes the findings of this study.

\section{DESCRIPTION OF EXPERIMENT}

Karava et al. [10] performed detailed Particle Image Velocimetry (PIV) measurements to evaluate natural ventilation for isolated building with Boundary Layer Wind Tunnel in Concordia University. The open-circuit wind tunnel has a length of $12 \mathrm{~m}$ and a cross-section of $1.8 \times 1.8 \mathrm{~m}^{2}$. For PIV measurements accommodation, a glass window extension was constructed near wind tunnel outlet. A 1:200 scaled down flat roof building were with 2 mm cast transparent polymethylmethacrylate (PMMA). The building model has dimension $0.1 \mathrm{~m} \times 0.1 \mathrm{~m} \times 0.08 \mathrm{~m}$ (width $\mathrm{x}$ depth $\mathrm{x}$ height) corresponding to $20 \mathrm{~m} \times 20 \mathrm{~m}$ x $16 \mathrm{~m}$ in full scale dimension. Figure 1 depicts the dimension of the building model. Various combinations of opening position and wall porosity were tested. Three opening positions namely top, center and bottom were considered [10]. In this paper, model with both windward and leeward openings located at the center and with porosity of $10 \%$ was referred.

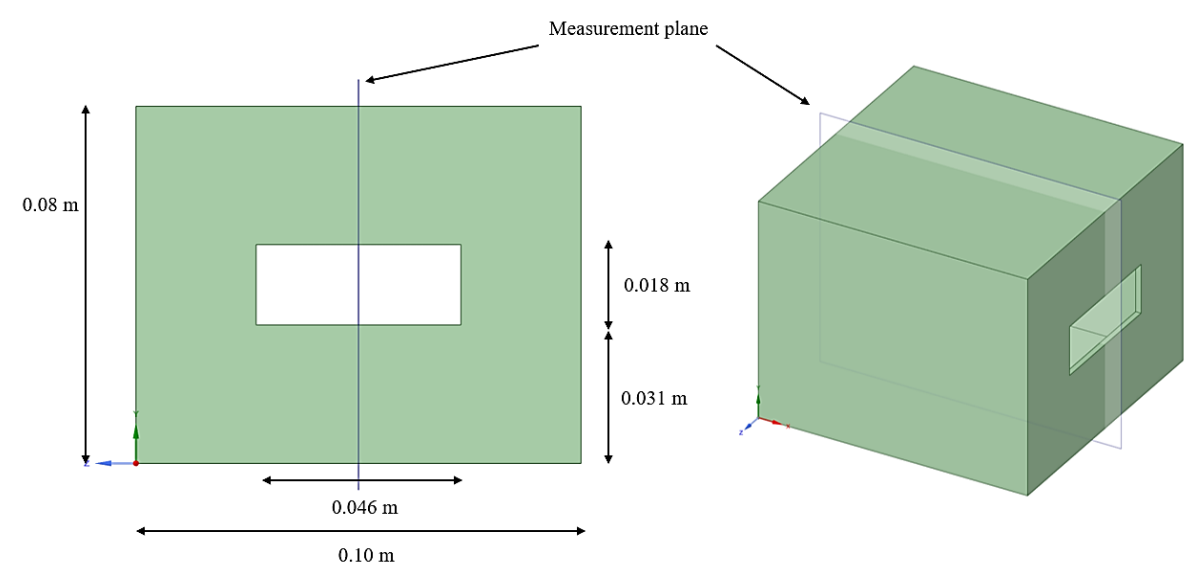

Figure 1. Dimension of basic building model [10]

The building model was placed in the glass window extension and orientated with openings perpendicular to incoming flow. The floor was covered with extrude polystyrene (XPS) and carpet along the wind tunnel to reproduce an open terrain roughness profile. The aerodynamic roughness length of $z_{0}=0.025 \mathrm{~mm}$ in reduced scale equating to $0.005 \mathrm{~m}$ in real scale. A mean wind speed at reference height of $6.97 \mathrm{~m} / \mathrm{s}$ and $10 \%$ of turbulence intensity were measured. The measurements were done in an empty wind tunnel using a hot film probe. The turbulence intensity near ground level and gradient height are around $17 \%$ and 5\%, respectively. The PIV measurements were performed in horizontal plane through the center of openings and in vertical plane of symmetry [10]. The results were used for model validation purpose in this paper.

\section{NUMERICAL STUDY: MODEL SETUP AND CFD SIMULATION}

\section{Model Case, Computational Domain and Grids}

Karava's building model [10] was selected as reference model. The overall dimension is presented in Figure 2. The basic building model was used to performed grid analysis study with validation to the experiment by Karava et al. The basic building model was then reproduced into roofed building model. Two different types of gable roof with various roof angles and roof openings were added to the basic building model. Each type of gable roof building was tested with four different roof pitches, namely $15^{\circ}, 25^{\circ}, 35^{\circ}$ and $45^{\circ}$ as shown in Table 1 . Figures $2 \mathrm{a}$ and $2 \mathrm{~b}$ describe the dimension of the standard gable roof and tipped gable roof (aka saltbox roof) of $15^{\circ}$ roof pitch. The window and roof openings have a width of $46 \mathrm{~mm}$ and different height of $18 \mathrm{~mm}$ and $9 \mathrm{~mm}$, respectively. The centre of window openings is at $\mathrm{h}=0.04$ $\mathrm{m}$ and roof openings at $\mathrm{h}=0.067 \mathrm{~m}$. The building wall thickness was maintained as $2 \mathrm{~mm}$ proposed by Karava et al [10]. 

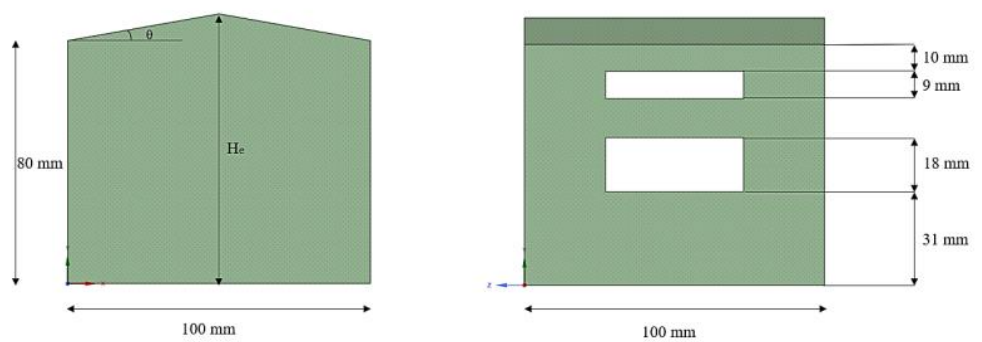

(a)
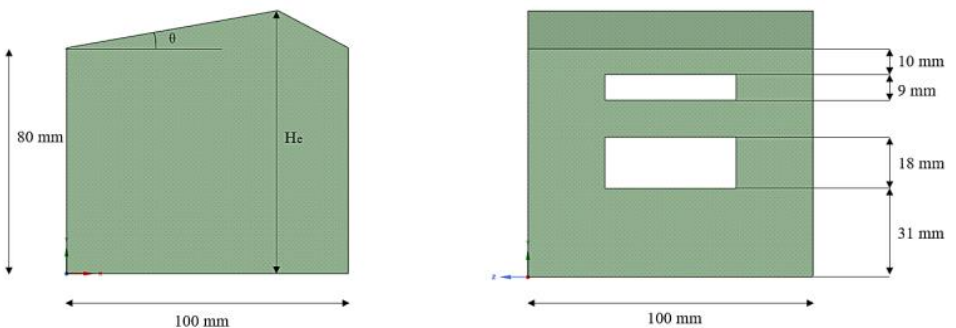

(b)

Figure 2. Dimension of: (a) standard gable roof and (b) saltbox roof

Table 1. Model cases of gable and saltbox roof

\begin{tabular}{c|c}
\hline Roof Shape & Roof Pitches \\
\hline Gable Roof & $15^{\circ}, 25^{\circ}, 35^{\circ}$ and $45^{\circ}$ \\
Saltbox Roof & $15^{\circ}, 25^{\circ}, 35^{\circ}$ and $45^{\circ}$ \\
\hline
\end{tabular}

The computational domain was constructed according to the best CFD practice guideline from Franke et al. [11] and Tominaga et al. [12]. The upstream length was shorten to $3 \mathrm{H}$ instead of $5 \mathrm{H}$ to restrict the extend of unintended streamwise gradient [11]. The top and side wall of the domain were constructed 5H away from the building model and the downstream length was $15 \mathrm{H}$ [5]. Figure 3 illustrates the dimension of the computational domain, where $\mathrm{H}$ is the effective building height measured from ground.

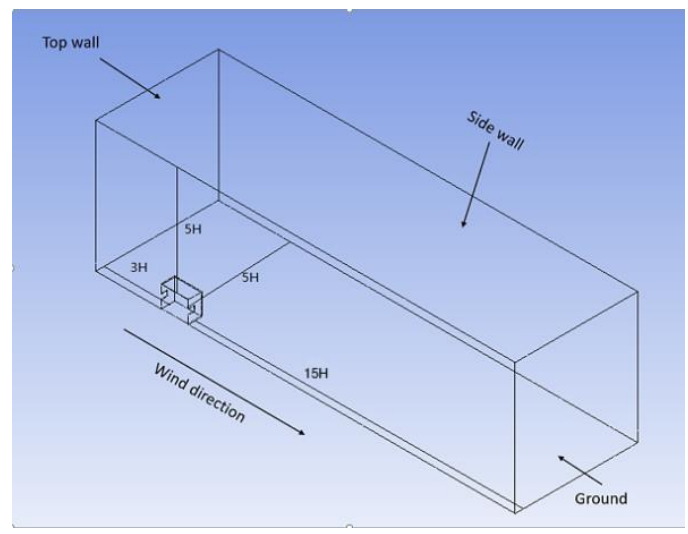

Figure 3. Dimension of computational domain

Mosaic ${ }^{\mathrm{TM}}$ meshing technology was selected to produce computational grids. It offers the benefits of high-quality octree hexahedron in bulk region, allows automatic connection of elements despite its type, and high efficiency in solving fluid flow in complex geometries [13]. Mosaic ${ }^{\mathrm{TM}}$ meshing technology also speeds up the solver by $10-50 \%$ offering similar results and consuming lesser machine memory. The model geometry and computational domain were first remeshed with tetrahedral elements using local scope sizing function based on the curvature, proximity and soft size requirements. The mesh type was then converted into Poly-hexcore by preserving average edge length consistency with 
triangular surface mesh [13]. Figures $4 \mathrm{a}$ and $4 \mathrm{~b}$ depict the triangular surface mesh used to generate hexcore volume mesh and poly-hexcore mesh generated for case of gable roof with $15^{\circ}$ roof pitch.

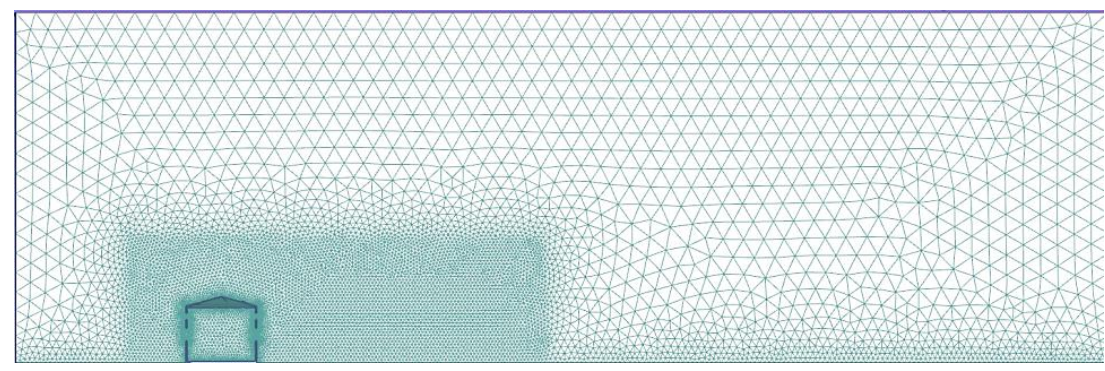

(a)

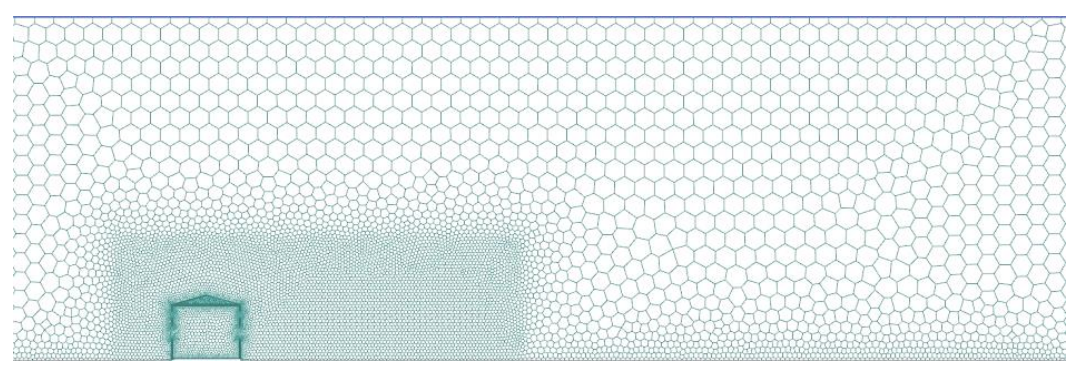

(b)

Figure 4. (a) Triangular surface mesh and (b) Poly-hexcore mesh generated for gable roof building with $15^{\circ}$ roof angle

\section{Boundary Conditions}

The boundary condition of measured mean wind speed and turbulent intensity from the wind tunnel experiment were employed at the inlet plane. The wind velocity profile at the inlet was determined in accordance to the logarithm law with $\mathrm{z}_{0}=0.025 \mathrm{~mm}$ using equation (1) where the $\mathrm{u}^{*} \mathrm{ABL}$ is the wind speed at reference height and $\kappa$ is the von karman constant.. The mean wind speed $\{U(z)\}$ and turbulent intensity $\left\{I_{u}(z)\right\}$ were then used to calculate the turbulent kinetic energy $\{\mathrm{k}(\mathrm{z})\}$ at reference height $\{$ equation $(2)\}$. The selected kinetic energy factor $\{\alpha\}$ was set at 1 as proposed by Tominaga et al. [12]. The rate of turbulence dissipation $\{\varepsilon\}$ and specific dissipation rate $\{\omega\}$ were calculated using equation (3) and (4), respectively. The empirical constant, $C_{\mu}=0.09$ which suggested by Ramponi et al. [5] was applied. Standard wall function by Launder and Spalding with modified roughness height $\left\{\mathrm{z}_{0}\right\}$ was applied at the ground surface [14]. This is to simulate the building on a grass covered terrain with scaled down length of $0.00003 \mathrm{~m}$. Equation (5) derived by Blocken et al. [15] was used to determine the sand grain roughness height $\left\{\mathrm{k}_{\mathrm{s}}\right\}$, where the selected value for $\mathrm{C}_{\mathrm{s}}$ was 0.42 . Zero static pressure was imposed at the outlet and symmetry plane. Zero normal gradients and velocity correspond to zero shear condition was applied at the top and side plane. Standard wall function without roughness height was applied to the tested building model.

$$
\begin{gathered}
U(z)=\frac{u_{A B L}^{*}}{\kappa} \ln \left(\frac{z+z_{0}}{z}\right) \\
k(z)=\alpha\left(I_{u}(z) U(z)\right)^{2} \\
\varepsilon(z)=\left(\frac{u_{A B L}^{* 3}}{\kappa\left(\mathrm{z}+z_{0}\right)}\right) \\
\omega(z)=\frac{\varepsilon(z)}{C_{\mu} k(z)} \\
k_{s}=\frac{9.793 z_{0}}{C_{s}}
\end{gathered}
$$

\section{Solver Settings}

Ansys 2019 R3 was used to perform 3D RANS steady-state simulation in combination with SST k- $\omega$ turbulence model. SST k- $\omega$ was selected due to its better accuracy in comparison with PIV measurements by Karava et al. [10], and the reliability was confirmed by Ramponi et al. [5]. SIMPLE algorithm based on Green Gauss node spatial discretization was selected in this study. Second order upwind discretization and pressure interpolation was imposed to the convection 
and viscous terms of the governing equation. Convergence criteria was expected when the scaled residual recedes down to $10^{-4}$.

\section{Grid Sensitivity Analysis}

A detailed grid sensitivity analysis and model validation was performed on basic building model to obtain grid independent result. Three grids with different sizing and cell counts (Grid A, B and C with cell count number of 319426 , 473837 and 749997, respectively) were created for the analysis. The velocity vector and $\mathrm{U} / \mathrm{U}_{\text {ref }}$ obtained were compared to the PIV measurements performed by Karava et al. [10]. Figures 5 and 6 compare the velocity vector field and U/ $\mathrm{U}_{\text {ref }}$ plots acquired with the PIV measurements and CFD simulations, respectively. The main feature of the flow reproduced by CFD simulations shows valued agreement to the PIV measurements, both indoor and outdoor airflow. Moreover, the $\mathrm{U} / \mathrm{U}_{\text {ref }}$ along the window centre line shows well agreement to experimental results. As proposed by Ramponi et al., the numerical model tends to overestimate the mean wind speed near the openings [5]. The shading effects and reflections caused the inaccurate prediction of the PIV measurements [10]. In opposition, the prediction of approaching and indoor air movement is described fairly accurate. As shown in Figure 5, grid $\mathrm{C}$ shows rather accurate prediction compared to experimental results among three meshes. Grid $\mathrm{C}$ is therefore retained for the subsequent simulations.

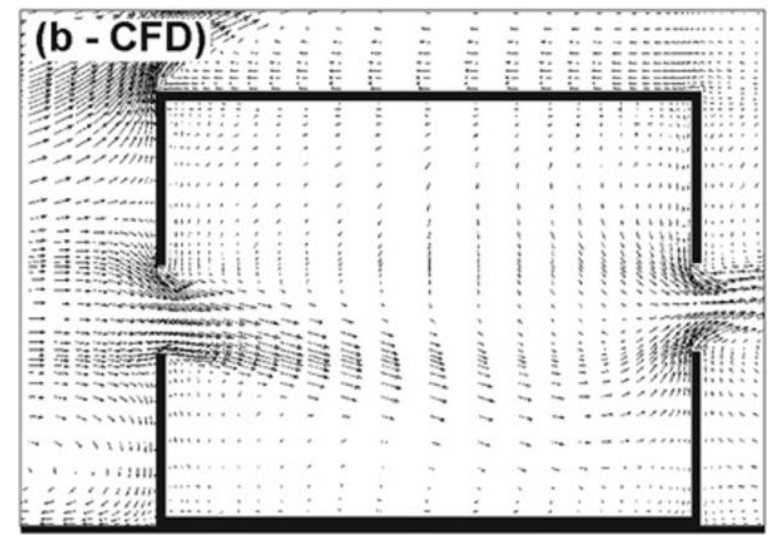

(a)

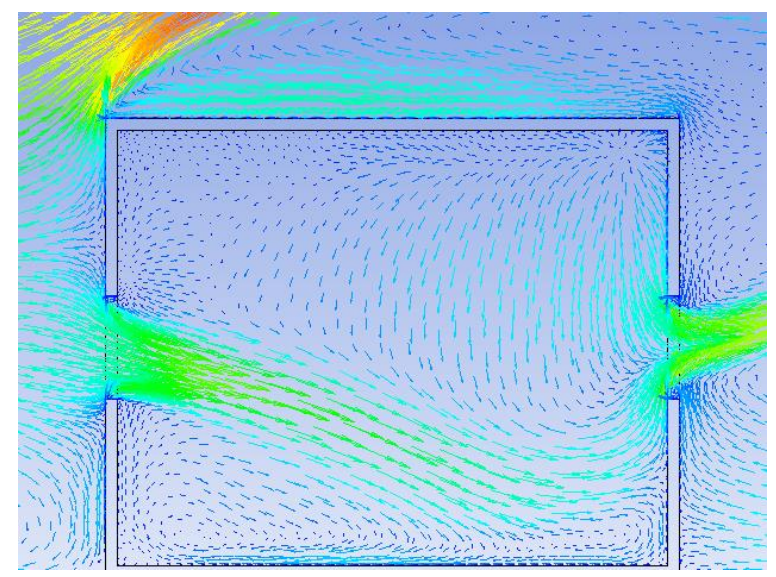

(c)

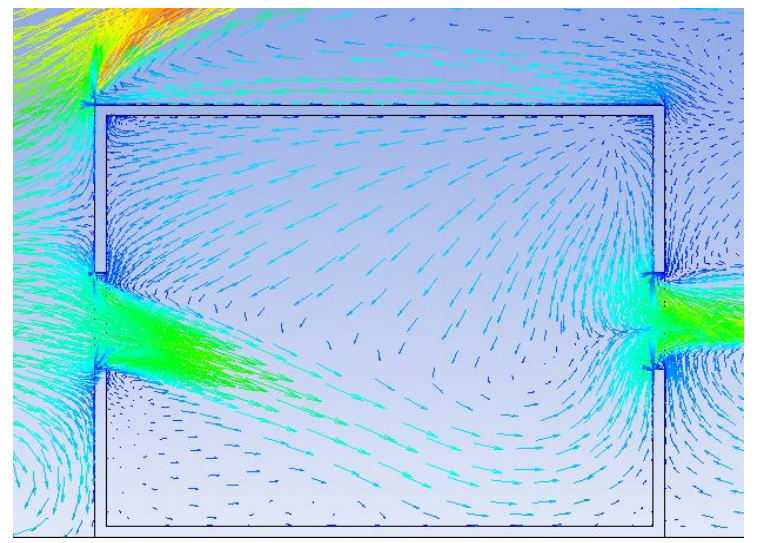

(b)

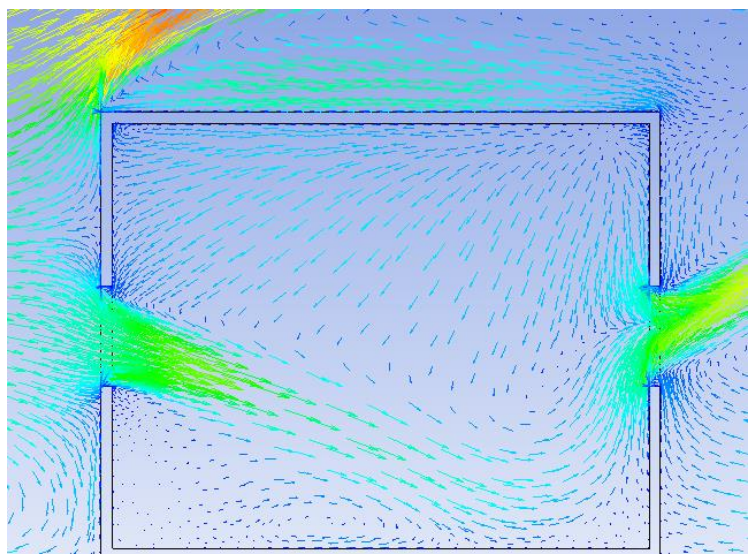

(d)

Figure 5. Velocity vector of: (a) PIV measurement by Karava et al. [10], (b) Grid A (319426 cell count), (c) Grid B (473837 cell count) and (d) Grid C (749997 cell count) 


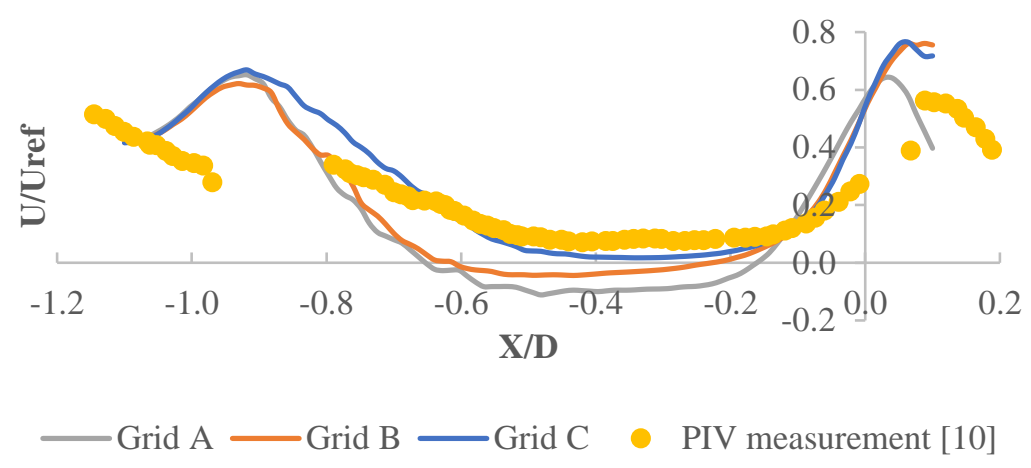

Figure 6. Comparison of $\mathrm{U} / \mathrm{U}_{\text {ref }}$ along horizontal centre line for three different girds and PIV measurement

\section{EFFECTS OF ROOF CONFIGURATION ON AIR FLOW CHARACTERISTICS AROUND THE BUILDING}

\section{Dimensionless Streamwise Velocity Ratio}

Figure 7 depicts the $\mathrm{U} / \mathrm{U}_{\text {ref }}$ profile along the horizontal centre line of window opening for gable roof and saltbox roof with various roof angles. The figure clearly shows that the $\mathrm{U} / \mathrm{U}_{\text {ref }}$ across the building depend on the roof angle. The $\mathrm{U} / \mathrm{U}_{\text {ref }}$ across the building shows increment as the roof pitch increases. Receding $\mathrm{U} / \mathrm{U}_{\text {ref }}$ is observed when the roof pitch increases from $35^{\circ}$ to $45^{\circ}$. The wind flow enters and exit the building in an accelerating velocity due to the pressure difference between interior and exterior. The wind flow is observed to slowly decelerate across the building relative to the comparatively constant pressure within the building. In general, $35^{\circ}$ roof pitch gives the best overall U/ $\mathrm{U}_{\text {ref }}$ profile across the building, followed by $45^{\circ}, 25^{\circ}$ and lastly $15^{\circ}$. In other words, $35^{\circ}$ roof angle is the tipping point for the $\mathrm{U} / \mathrm{U}_{\text {ref }}$ across the building.
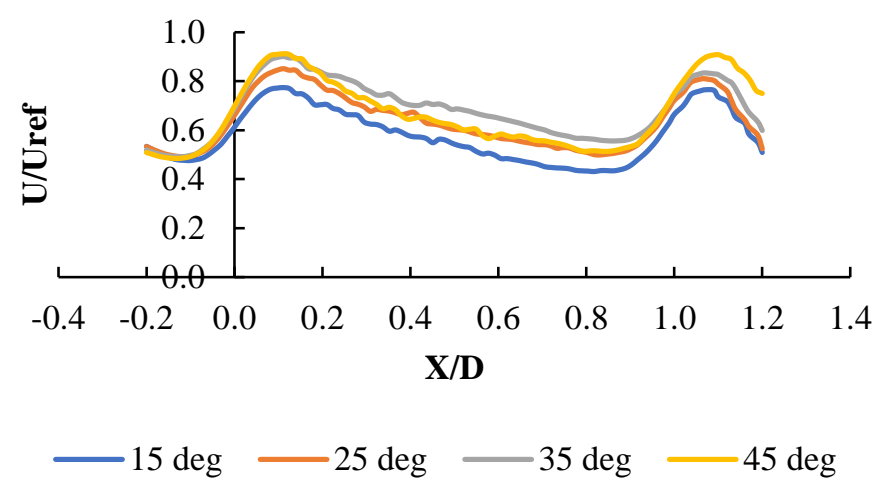

(a)

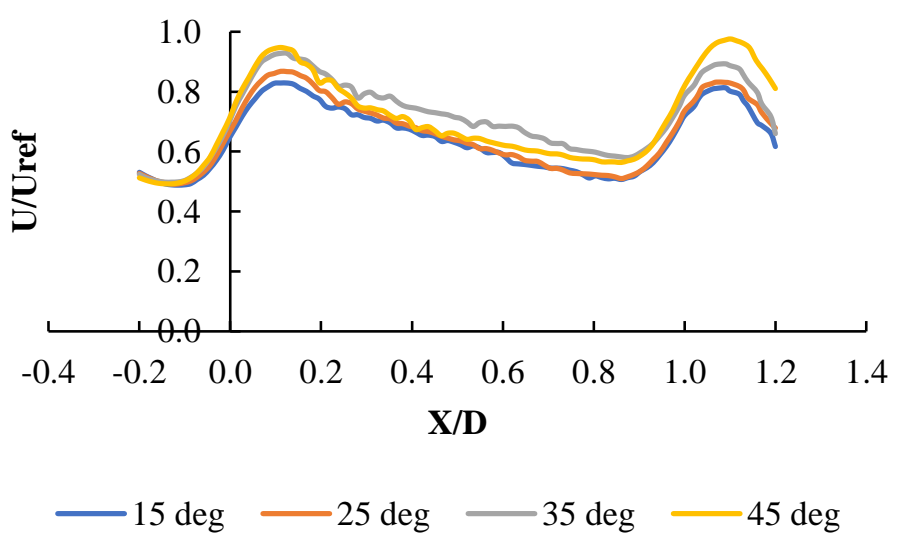

(b)

Figure 7. U/Uref along the centre line of window opening of: (a) Gable roof and (b) Saltbox roof with various roof angles

Figures 8 and 9 illustrate the $\mathrm{U} / \mathrm{U}_{\text {ref }}$ contours of gable roof and saltbox roof buildings with various roof pitches. In both roof shapes cases, the peak value of $U / U_{\text {ref }}$ was observed over the roof. This is due to the impinging effect caused by the incoming wind and flow separation at windward corner. Large flow separation was detected in $15^{\circ}$ gable roof while 
only little flow separation was spotted in $15^{\circ}$ saltbox roof. The impinging effect by the wind was noticed to be intensified when the roof pitch increases and little flow separation at windward corner was observed in the rest of the cases. However, large flow separation was observed over the ridge as the roof pitch increases. From the figures, separation zones developed at leeward side just after the roof ridge and consequent to the occurrence of recirculation region. The flow separation over the roof ridge caused a reversed flow further away after the building which subsequent to the recirculation behind the building. The recirculation zone developed at the leeward side grows larger and spreads up to the ridge as the roof pitch increases. This is consistent with the findings from Ozmen et al. [16]. The formation of recirculation zone behind the building limits the extend of airflow exit from the leeward openings.

Inside the building, the wind flow enters from the window opening was directed downward immediately which is attributed to the opening location and formation of recirculation zone in front of the building. The vortex trapped the air and kept it exterior, however, the air around the recirculation enters the building in the form of down draft. As the roof pitch increases, the wind flow directly flows towards the leeward opening due to the increment of velocity. The wind speed decelerated across the building and recovered as it approaches the leeward opening. At the roof opening level, the flow enters the building was directed slightly upward due to the upstream upward flow which is consistent with the findings from Karava et al. [10]. Although both roof shapes exhibit similar air flow pattern, however saltbox roof provides higher wind flow velocity across the building. This probably due to saltbox roof configuration enhanced the impinging effect and limited the flow separation caused by the incoming wind and windward leading edge of the building.

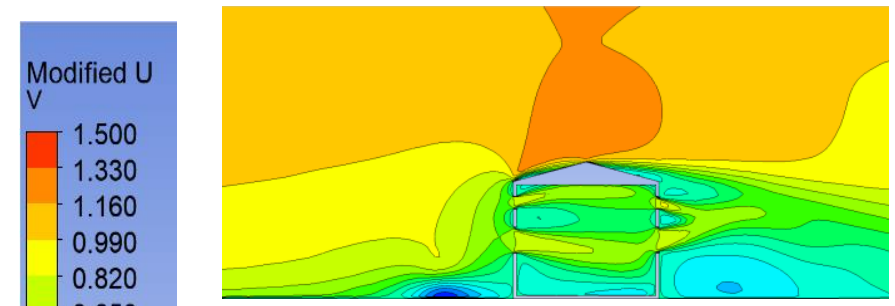

(a)

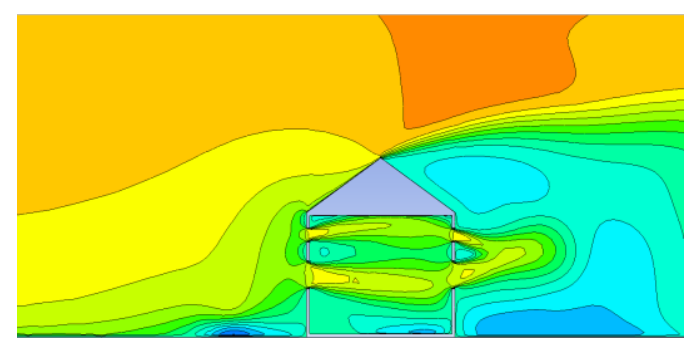

(c)

Figure 8. $\mathrm{U} / \mathrm{U}_{\text {ref }}$ contour of gable roof with (a) $15^{\circ}$, (b) $25^{\circ}$, (c) $35^{\circ}$ and (d) $45^{\circ}$
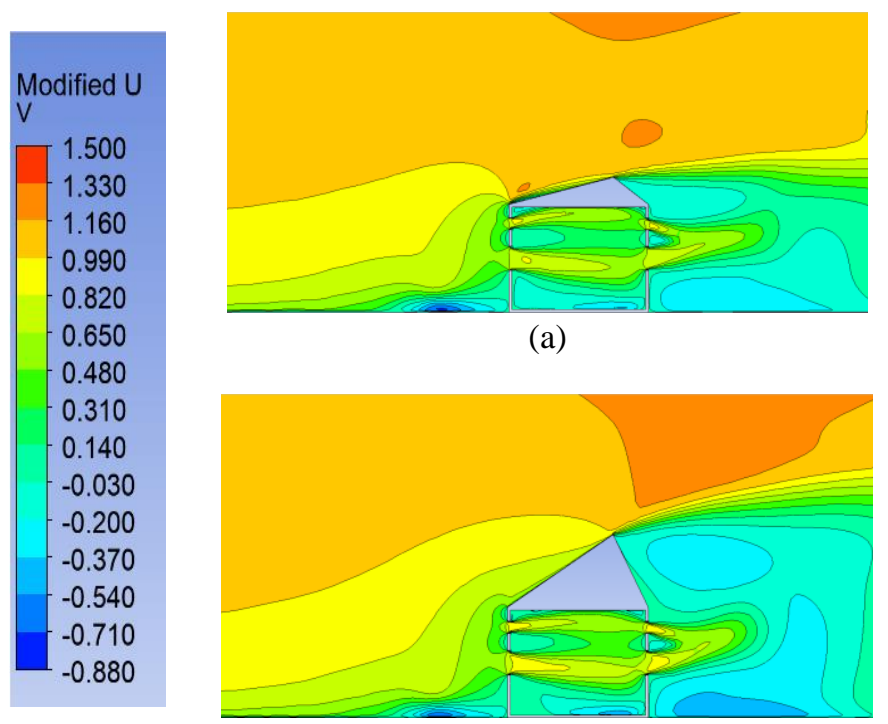

(c) (a)

0.650

$-0.480$

$-0.310$

$-0.140$

$-0.030$

$-0.200$

$-0.370$

$-0.540$

$-0.710$

$-0.880$

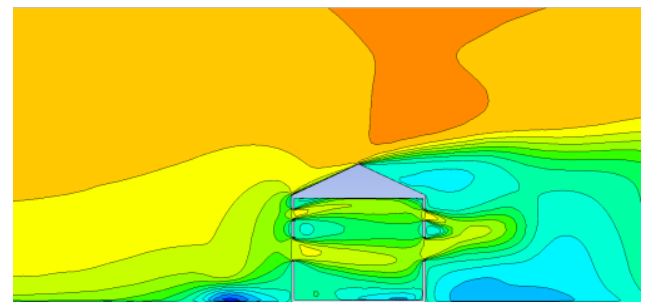

(b)

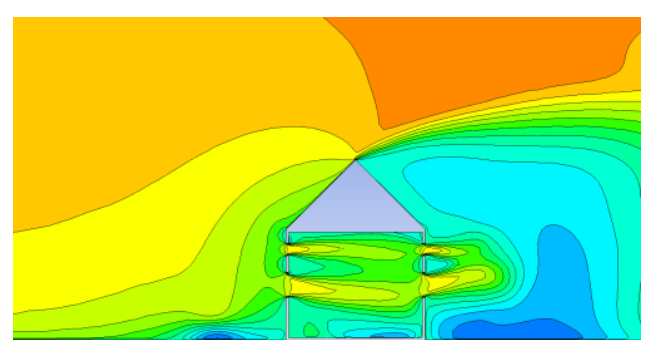

(d)

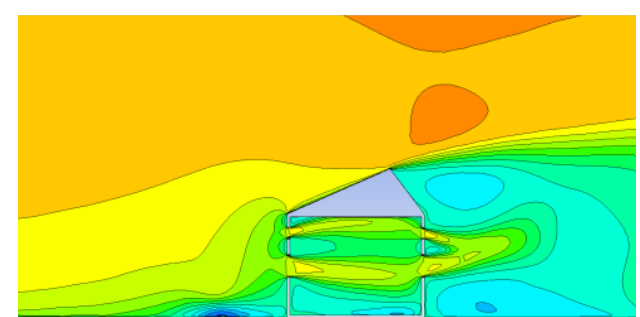

(b)

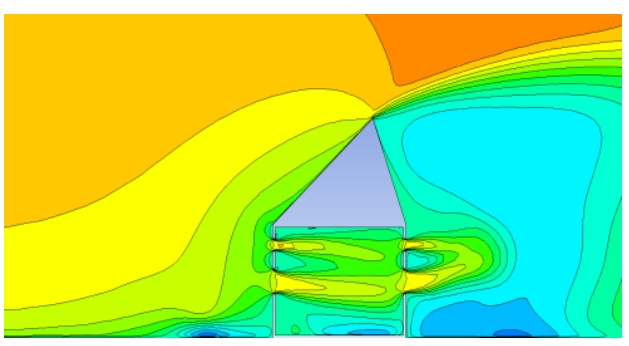

(d)

Figure 9. $\mathrm{U} / \mathrm{U}_{\text {ref }}$ contour of saltbox roof with (a) $15^{\circ},(\mathrm{b}) 25^{\circ},(\mathrm{c}) 35^{\circ}$ and (d) $45^{\circ}$. 


\section{Spatial Distribution of Pressure Coefficient}

The pressure drops along horizontal center line across the building with different roof configuration were compared as depicted in Figure 10. The pressure drops across the building shows increment as the roof pitch increases in both roof shape cases. For gable roof cases, the pressure drops between $15^{\circ}$ and $25^{\circ}$ roof pitch is comparably significant relative to the others. The critical angle is in between $15^{\circ}$ and $25^{\circ}$ which is agreeing with the critical gable roof angle of $18^{\circ}$ [7]. The pressure drops remained as the roof pitch exceed $35^{\circ}$ as clearly shown in Figure 10. For saltbox roof cases, the pressure changes between $15^{\circ}$ and $25^{\circ}$ roof pitches is rather insignificant compared to pressure change between $25^{\circ}$ and $35^{\circ}$ roof pitches. Similar to gable roof, the pressure drops exhibited nearly identical pattern in $35^{\circ}$ and $45^{\circ}$ roof pitch. In other words, the critical roof angle for saltbox roof is in between $25^{\circ}$ and $35^{\circ}$. In general, saltbox roof offer better pressure drops across the building than gable roof.

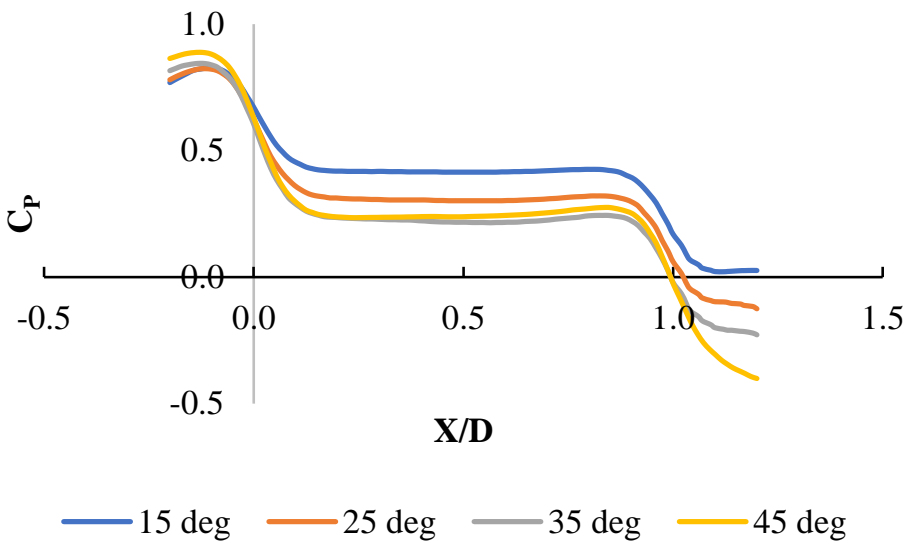

(a)

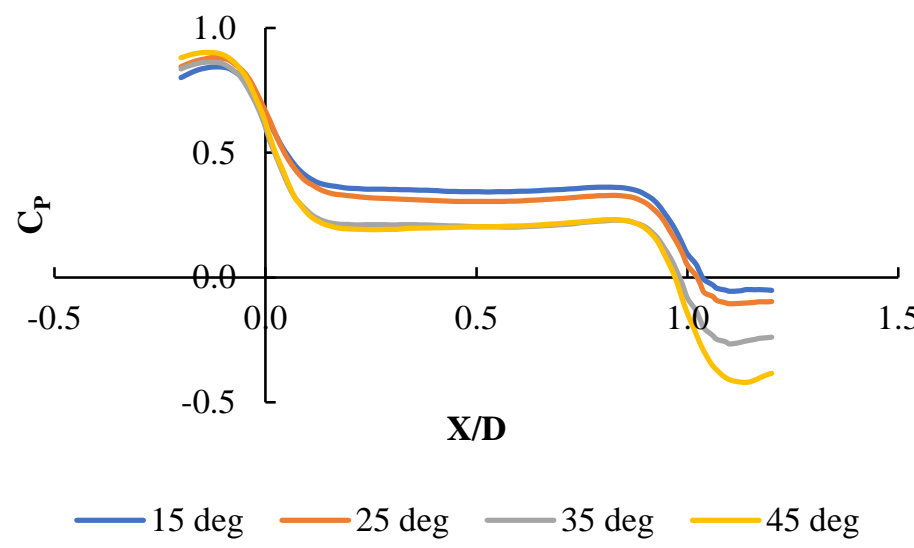

(b)

Figure 10. Pressure drop across the building for (a) gable roof and (b) saltbox roof

Figures 11 and 12 compare the spatial distribution of pressure coefficient for gable roof and saltbox roof with various roof angles. In accordance to the roof pitch increment, the positive peak pressure before the building become larger. This is due to the blockage caused by the roof configuration [7]. Little negative zone was observed at the windward corner in the cases of $15^{\circ}$ roof pitch caused by the flow separation. The negative zone vanished and moved toward the roof ridge as the roof pitch increases due to the enhancement of impinging effect. In opposition, the negative pressure behind the building enlarged as the roof pitch increases. The enlarging negative pressure was a consequence of flow separation at the roof ridge.

The effect of roof configuration can be clearly seen from Figures 11 and 12. Slight difference in roof configuration can caused significant pressure changes around the building. The extend of windward roof in saltbox roof cases cause larger flow separation over the roof ridge. This directly induced major pressure difference in the upstream, interior and downstream region. Moreover, the induced pressure difference has a significant interrelation with the wind speed across the building which obeys the Bernoulli principle. 


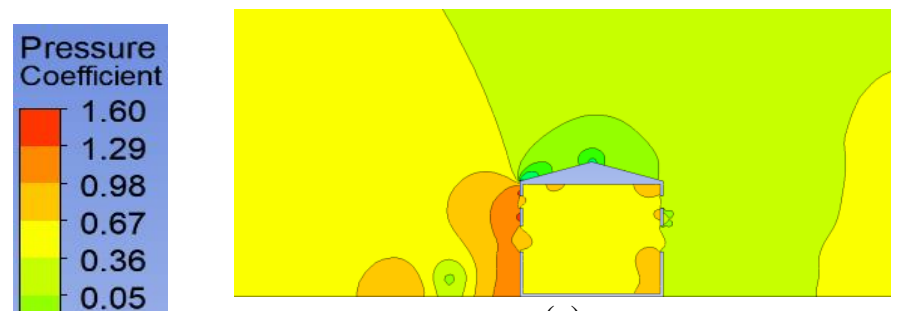

(a)

$-0.26$

$-0.58$

$-0.89$

$-1.20$

$-1.51$

$-1.82$

$-2.13$

$-2.44$

$-2.75$

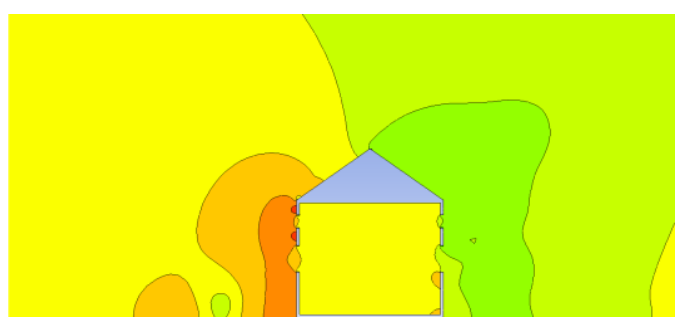

(c)

Figure 11. Spatial distribution of $C_{P}$ for gable roof with (a) $15^{\circ}$, (b) $25^{\circ}$, (c) $35^{\circ}$ and (d) $45^{\circ}$

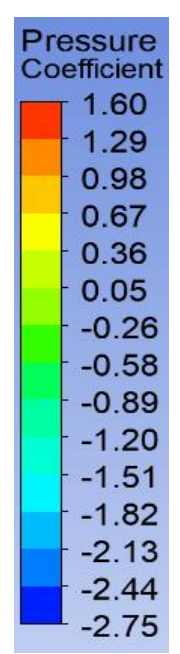

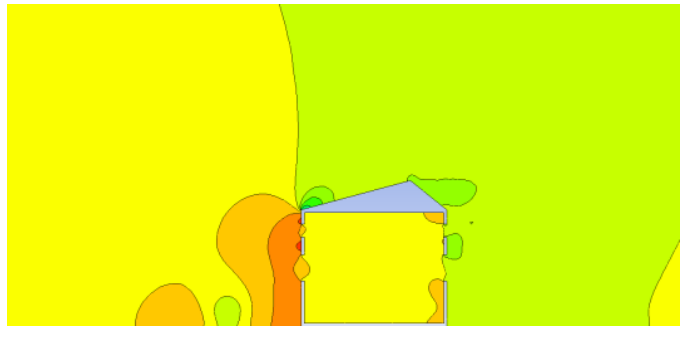

(a)

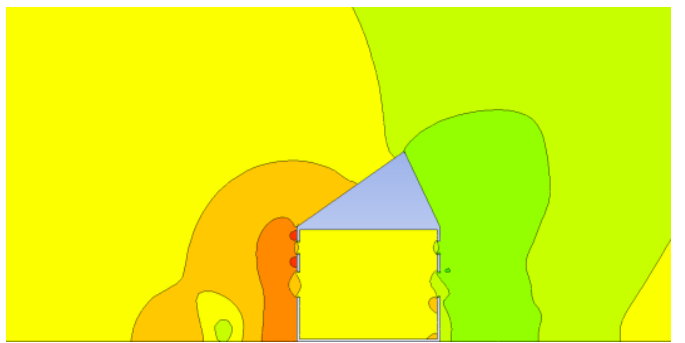

(c)

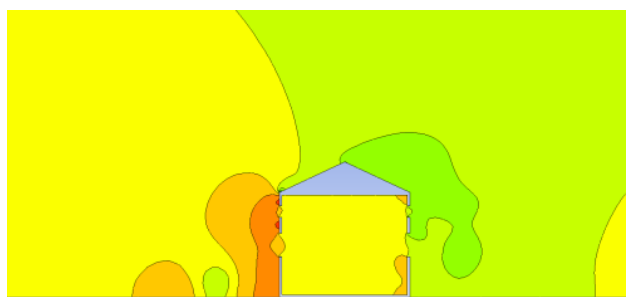

(b)

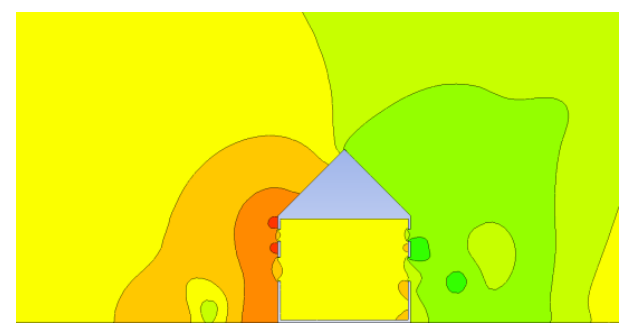

(d)

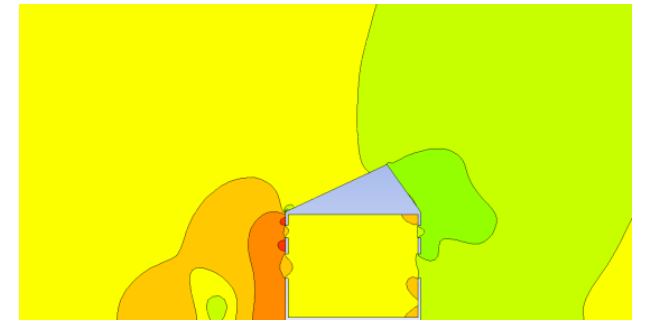

(b)

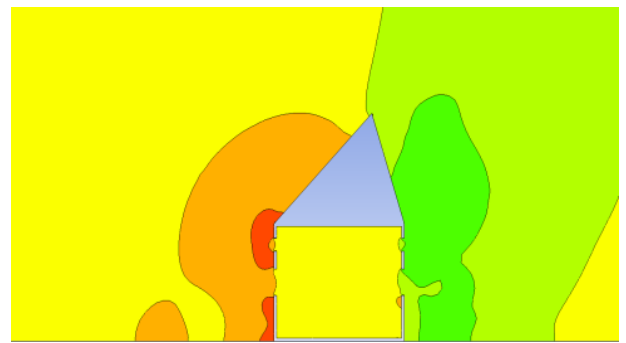

(d)

Figure 12. Spatial distribution of $\mathrm{C}_{\mathrm{P}}$ for saltbox roof with (a) $15^{\circ}$, (b) $25^{\circ}$, (c) $35^{\circ}$ and (d) $45^{\circ}$

\section{Spatial Distribution of Turbulence Kinetic Energy}

Figures 13 and 14 illustrate the distribution of TKE for gable roof and saltbox roof with various roof angles. TKE was found to be firmly related to the wind speed around the building. TKE represents the flow power of the air around the building and thus accounts for the characteristic of the air flow [17]. The velocity is relatively lower when the production of TKE increases. The production of TKE was observed at the leeward side of the roof due to the flow separation at the roof ridge. The peak zone was continue growing as the roof pitch increases due to the increment of impinging effect at the windward roof. The enhanced impinging effect induced higher wind speed over the roof and hence larger region of TKE production at the leeward side. There is a complicated interaction between the eddy near the ridge and the recirculation formation by the building [7]. A smaller production of TKE was spotted near the leeward window opening. This was due to the reversed flow caused by the flow separation at the roof ridge. The smaller production of TKE limited the extent of the wind speed exit from the leeward window. The region was also noticed growing larger as the roof pitch increases. The concentrated TKE region over the leeward roof and saturated TKE region in the building induced high differential pressure between the windward side of the building and the interior. As such, this differential pressure alters the ventilation performance of the building. 


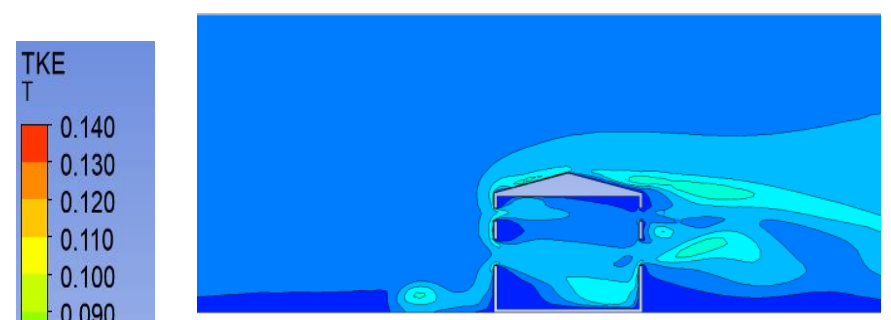

(a)

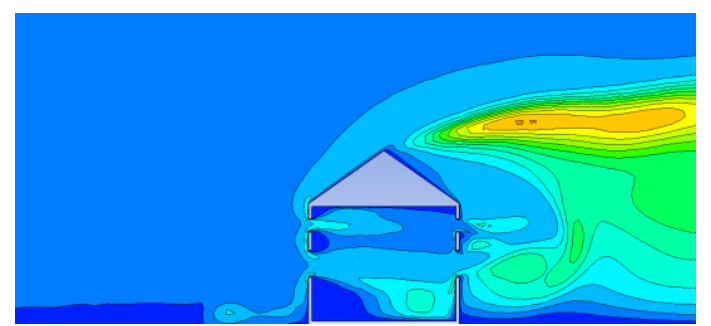

(c)

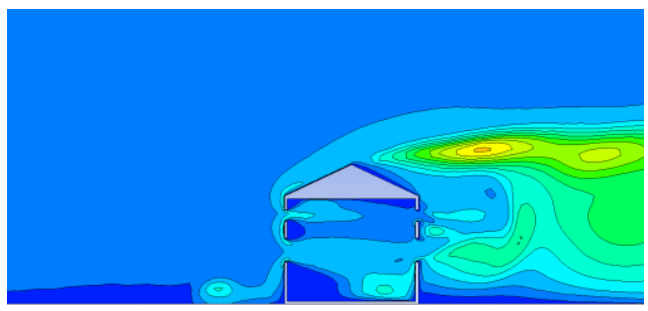

(b)

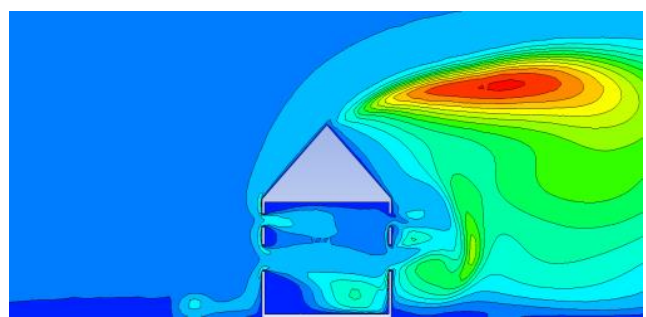

(d)

Figure 13. Spatial distribution of TKE for gable roof with (a) $15^{\circ}$, (b) $25^{\circ}$, (c) $35^{\circ}$ and (d) $45^{\circ}$
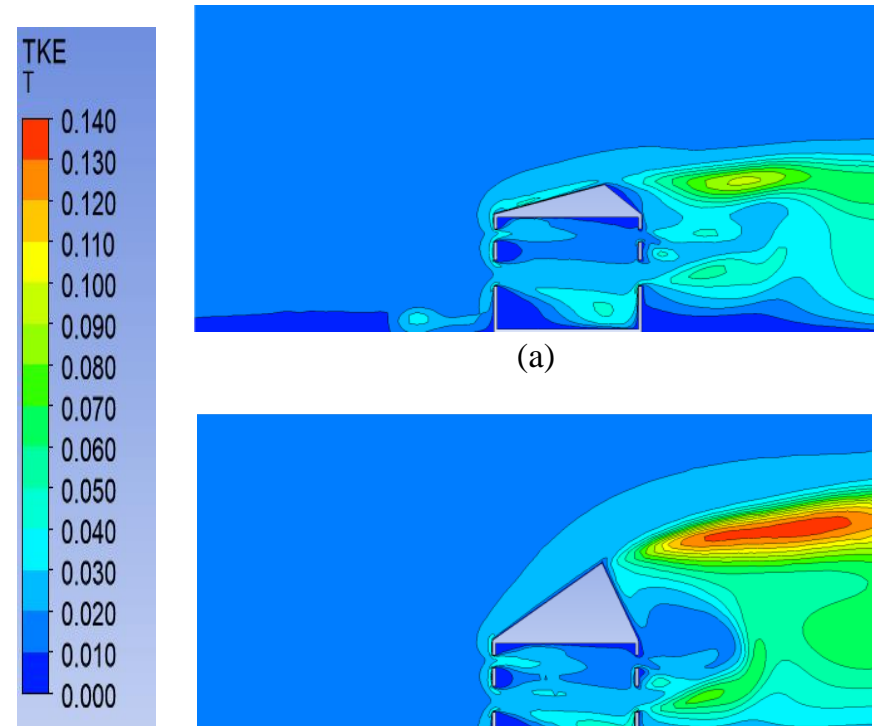

(a)

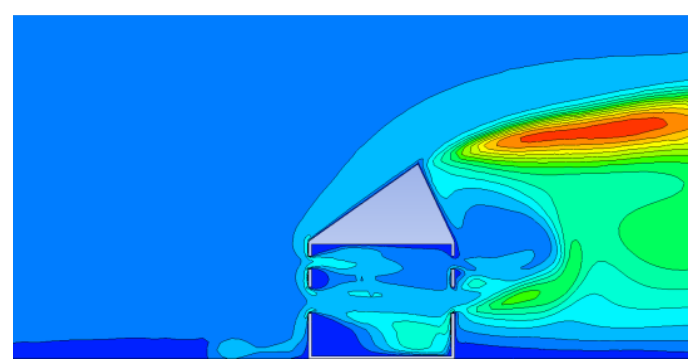

(c)

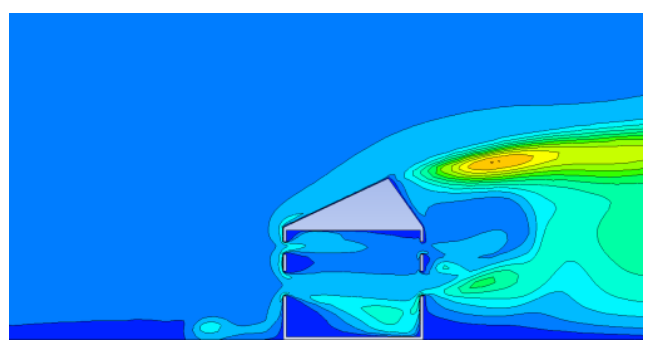

(b)

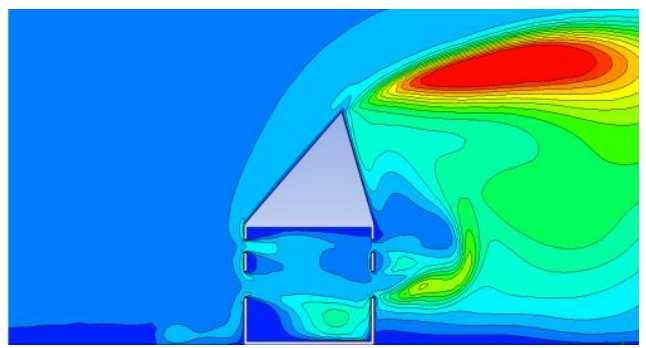

(d)

Figure 14. Spatial distribution of TKE for saltbox roof with (a) $15^{\circ}$, (b) $25^{\circ}$, (c) $35^{\circ}$ and (d) $45^{\circ}$

\section{CONCLUSIONS AND FUTURE RECOMMENDATIONS}

Numerical investigations based on steady RANS were conducted on isolated building with two different roof configurations, namely gable roof and saltbox roof with various roof angle. Information on the flow pattern and characteristics was obtained from the contours and plots generated and exported by Ansys 2019 R3. The numerical results revealed that the mean velocity ratio, spatial distribution of pressure coefficient and turbulence kinetic energy around and within the building strongly depend on the roof configurations. As such, higher wind speed and differential pressure between indoor and outdoor induced better ventilation performance. In contrast, the effect of increasing production of TKE over the roof ridge on natural ventilation caused by the increasing roof pitch is relatively lower. The pressure difference and mean velocity ratio along the center line of the building increases as the roof pitch become steeper. However, the slight difference in roof configuration offered higher mean velocity and pressure difference in saltbox roof. This is due to the extent of windward roof height which reinforced the impinging effect at the windward corner. The boosted impinging effect also limited the movement of separated flow at the windward corner. The separated flow at the windward corner do not reattach onto the roof but are noticed to develop vortices on the leeward side. The vortices caused by the flow separation extended along the mixing later behind the building at the roof level. The increment of roof angle induced higher velocity gradient and thus the vortex near the leeward roof grew stronger and spread up to the roof ridge.

The roof shapes and angles are found to be significantly influencing the air flow characteristics around the building. However, the present study was conducted with the negligence of the surrounding temperature, angle of attack of 
incoming wind and the surrounding obstacles. Further investigation on the effect of roof topology should consider the aforementioned parameters to improve human thermal comfort and promote natural ventilation.

\section{ACKNOWLEDGMENTS}

The project is funded by the Ministry of Higher Education Malaysia, under the Fundamental Research Grant Scheme (FRGS Grant No: FRGS/1/2016/TK07/SEGI/02/1).

\section{REFERENCES}

[1] Department of Standards Malaysia, "MS1525-2014 Code of practice on energy efficiency and use of renewable energy for non residential buildings ( $2^{\text {nd }}$ Revision)" 2014.

[2] J. Kindangen, G. Krauss, and P. Depecker, "Effects of roof shapes on wind-induced air motion inside buildings," Building and Environment, vol. 32, no. 1, pp. 1-11, 1997.

[3] M. Mahdavinejad and K. Javanroodi, "Impact of roof shape on air pressure, wind flow and indoor temperature of residential buildings," International Journal of Sustainable Building Technology and Urban Development, vol. 7, no. 2, pp. 87-103, 2016.

[4] Y. L. Xu and G. F. Reardon, "Variations of wind pressure on hip roofs with roof pitch," Journal of Wind Engineering and Industrial Aerodynamics, vol. 73, no. 3, pp. 267-284, 1998.

[5] R. Ramponi and B. Blocken, "CFD simulation of cross-ventilation for a generic isolated building: Impact of computational parameters," Building and Environment, vol. 53, pp. 34-48, 2012.

[6] L. K. Moey, N. M. Adam, and K. A. Ahmad, "Effect of venturi-shaped roof angle on air change rate of a stairwell in tropical climate," Journal of Mechanical Engineering, vol. 4, no. 4, pp. 135-150, 2017.

[7] Y. Tominaga, S. Akabayashi, T. Kitahara, and Y. Arinami, "Air flow around isolated gable-roof buildings with different roof pitches: Wind tunnel experiments and CFD simulations," Building and Environment, vol. 84, pp. 204-213, 2015.

[8] X. Zhou, Y. Zhang, L. Kang, and M. Gu, "CFD simulation of snow redistribution on gable roofs: Impact of roof slope,” Journal of Wind Engineering and Industrial Aerodynamics, vol. 185, pp. 16-32, 2019.

[9] M. G. Badas, S. Ferrari, M. Garau, and G. Querzoli, "On the effect of gable roof on natural ventilation in two-dimensional urban canyons," Journal of Wind Engineering and Industrial Aerodynamics, vol. 162, pp. 24-34, 2017.

[10] P. Karava, T. Stathopoulos, and A. K. Athienitis, "Airflow assessment in cross-ventilated buildings with operable façade elements,” Building and Environment, vol. 46, no. 1, pp. 266-279, 2011.

[11] J. Franke, A. Hellsten, H. Schlunzen, and B. Carissimo, "Best practice guideline for the CFD simulation of flows in the urban environment, " ISBN 3-00-018312-4, 2007.

[12] Y. Tominaga, A. Mochida, R. Yoshie, H. Kataoka, T. Nozu, M. Yoshikawa, and T. Shirasawa, "AIJ guidelines for practical applications of CFD to pedestrian wind environment around buildings," Journal of Wind Engineering and Industrial Aerodynamics, vol. 96, pp. 1749-1761, 2008.

[13] K. Zore, G. Parkhi, B. Sasanapuri, A. Varghese, "Ansys mosaic poly-hexcore mesh for high-lift aircraft configuration," $21^{\text {th }}$ Annual CFD Symposium, pp. 1-11, 2019.

[14] B. E. Launder and D. B. Spalding, "The numerical computation of turbulent flows," Numerical Prediction of Flow, Heat Transfer, Turbulence and Combustion, pp. 96-116, 1983.

[15] B. Blocken, T. van Hooff, L. Aanen, and B. Bronsema, "Computational analysis of the performance of a venturi-shaped roof for natural ventilation: Venturi-effect versus wind-blocking effect," Computers \& Fluids, vol. 48, no. 1, pp. 202-213, 2011.

[16] Y. Ozmen, E. Baydar, and J. P. A. J. van Beeck, "Wind flow over the low-rise building models with gabled roofs having different pitch angles," Building and Environment, vol. 95, pp. 63-74, 2016.

[17] S. Hawendi and S. Gao, "Impact of windward inlet-opening positions on fluctuation characteristics of wind-driven natural cross ventilation in an isolated house using LES," International Journal of Ventilation, vol. 17, no. 2, pp. 93-119, 2018. 